\title{
Feeding Intolerance and Vomiting Caused by Duodenal Pancreatic Heterotopia in a Neonate
}

\section{Duodenal Pankreas Heterotopisi Nedeniyle Beslenme Intoleransı ve Kusma Gelișen Bir Yenidoğan Olgusu}

\author{
Betül Siyah Bilgin1, Sevim Ünal1, Deniz Gönülal1, Ceyda Tuna Kırsaçlıoğlu2 \\ ${ }^{1}$ Ankara Children's Hematology-Oncology Research Hospital, Clinic of Neonatology, Ankara, Turkey \\ ${ }^{2}$ Ankara Children's Hematology-Oncology Research Hospital, Clinic of Pediatric Gastroenterology, Ankara, Turkey
}

\begin{abstract}
Pancreatic heterotopia (PH) is a congenital abnormality defined by the presence of an ectopic pancreatic tissue outside the usual anatomic location of the pancreas. The frequency of the disorder is reported to be $0.2-15 \%$ in autopsies, $1-2 \%$ in laparotomies. The most common locations are the stomach, duodenum and jejunum. The symptoms develop as per the localization particularly in the elderly. We presented a term neonate with a birth weight of $4460 \mathrm{gr}$ hospitalized due to bilious vomiting 10 days after birth. The neonate presented $17 \%$ of dehydration, jaundice, and hypochloremic alkalosis on admission. Upper gastrointestinal contrast study demonstrated delayed passage. A mass of lace appearance in the second part of the duodenum was observed by endoscopy and was surgically excised. The diagnosis of PH was made through histopathological analysis. We want to highlight that although relatively rare, PH should be considered in the differential diagnosis of neonates with vomiting and feeding intolerance. The mass must be excised, if the symptoms develop.

Keywords: Infant, newborn, vomiting, pancreatic heterotopia
\end{abstract}

ÖZ

Pankreas heterotopisi (PH) pankreasın anatomik konumu dışında ektopik yerleşimi olarak tanımlanan bir doğumsal anomalidir. Sıkı̆̆ı otopsilerde \%0,215, laparotomilerde \%1-2 olarak bildirilmektedir. Mide, duodenum ve jejunum en sık bildirilen yerleşim bölgeleridir. Semptomlar özellikle ileri yaşlarda, lokalizasyon yerine göre değişmektedir. Burada safralı kusma nedeniyle 10 günlükken yenidoğan yoğunbakım ünitesine yatıılan, 4460 gr doğmuş term bir yenidoğan sunulmuştur. Hastaneye yatıııldığında doğum ağırlığına göre \%17 kilo kaybı, sarılık ve hipokloremik alkalozu olan bebeğin, üst gastrointestinal kontrast çalışmasında intestinal pasajda gecikme saptandı. Hastanın endoskopik incelemesinde duodenumun ikinci kısmına yerleşmiş, dantel görünümlü bir kitle görüldü ve cerrahi tedavi uygulandı. Kitlenin histopatolojik değerlendirilmesiyle PH tanısı konuldu. Bu olgu nedeniyle safralı kusma ve beslenme intoleransı olan yenidoğanların ayırııı tanısında, nadir görülmekle birlikte PH'nin akılda bulundurulması gerektiği vurgulanmak istenmiştir. Semptomatik olgularda cerrahi tedavi uygulanmalıdır. Anahtar Kelimeler: Bebek, yenidoğan, kusma, pankreatik heterotopi 


\section{Introduction}

Pancreatic heterotopia $(\mathrm{PH})$ is a congenital abnormality referring to an ectopic pancreatic tissue outside the usual anatomic location of the pancreas (1). The first case of $\mathrm{PH}$ was originally described as a pathological entity by Jean Schutz in 1727 in the ileal diverticulum, but it was not histologically demonstrated. $\mathrm{PH}$ is most commonly located in the stomach (26\%), duodenum (28\%) and jejunum (16\%) and the lesion is generally of small size. Other locations are the gallbladder, liver, colon, appendix, omentum, Meckel's diverticulum, and ileum. These abnormalities are typically accidentally discovered during endoscopy, surgery, or autopsy, with an incidence of $1-2 \%$ in patients undergoing laparotomy, $0.2-$ $15 \%$ in autopsies, and $0.2 \%$ in upper abdominal operations (2).

Most of the patients are completely asymptomatic and the lesion is rarely considered as a possible cause of clinical symptoms. Although it is usually asymptomatic, some patients with $\mathrm{PH}$ may develop clinical symptoms such as abdominal pain, gastrointestinal bleeding, dyspepsia, obstruction, and complications including intussusception, pancreatitis, pseudocyst formation, insulinoma and pancreatic cancer. Malignancy related to $\mathrm{PH}$ particularly occurs in the elderly. The condition is generally determined after the fourth decade and the treatment is surgical resection to prevent complications and eliminate the symptoms (3). Herein, we presented a neonate with $\mathrm{PH}$ as a rare cause of bilious vomiting in the neonatal period, because the condition rarely becomes symptomatic in newborns.

\section{Case Report}

A 10-day old boy, born to a healthy 31 year-old mother's fourth pregnancy at 41 weeks via vaginal delivery, was admitted to our hospital due to vomiting. The neonate weighed $4460 \mathrm{~g}$ at birth and was hospitalized for respiratory distress. Ampicillin, gentamicin and nasal continuous positive airway pressure were applied for 2 days. He was discharged on the fourth postnatal day; but bilious vomiting was observed with a gradual increase in amount and frequency. The parents stated that the baby had neither urinated nor passed stool for 2 days. On admission, physical examination revealed $17 \%$ of weight loss, abdominal distention, jaundiced skin up to knees, subconjunctival hemorrhage. Absence of movement and Moro reflex on the right arm was considered to be as a result of brachial plexus injury during labour.

On admission, laboratory analysis revealed hypochloremic alkalosis (serum chloride level $92 \mathrm{mmol} / \mathrm{L}$, arterial blood gases; $\mathrm{pH} 7.56$, partial pressure of carbon dioxide $36 \mathrm{mmHg}$, partial pressure of oxygen $76.3 \mathrm{mmHg}$, and bicarbonate $32.4 \mathrm{mmol} / \mathrm{L}$ ) and indirect hyperbilirubinemia (total bilirubin $15.5 \mathrm{mg} / \mathrm{L}$ ). Plain abdominal radiography and ultrasonography (USG) showed normal findings, and echocardiography demonstrated mild septal hypertrophy. He was administered enteral nutrition every $3 \mathrm{~h}$. However, this procedure was stopped due to bilious vomiting and, parenteral nutrition was started. We also determined bilious drainage via nasogastric tube.

We ruled out ileus caused by sepsis or electrolyte-mineral abnormalities, adrenal insufficiency, and inborn errors of metabolism because the hemogram, acute phase reactants, biochemical analysis, ammonia, and metabolic screening were within the normal limits. As the plain abdominal radiography and USG revealed no abnormalities, we did not consider pyloric stenosis, intraabdominal mass or annular pancreas.

We evaluated the infant using upper gastrointestinal contrast study and observed normal findings except for delayed passage. We excluded pyloric stenosis, intestinal obstruction (intestinal atresia, malrotation, volvulus, web, mass, or other lesions), and gastroesophageal reflux disease as per the findings of the gastrointestnial USG and contrast study. We did not consider Hirschsprung disease because there was no history of delayed passage of the first meconium, constipation, abdominal distention, toxic megacolon, and failure to pass stool. Munchausen syndrome by proxy was ruled out according to the history. Intussusception was not considered as sausage-shaped abdominal mass and progressive symptoms were not observed.

Esophagogastroduodenoscopy revealed a mass of lace appearance in the second part of the duodenum, not completely obstructing the lumen. The mass did not allow the transition of the scope to the distal part and it was surgically excised (Figure 1). Histopathological examination demonstrated submucosal pancreatic tissue with pancreatic acini, ducts, and mixed non-islet cells (Figure 2). Enteral nutrition was administered to the infant 5 days after the operation, and feeding intolerance did not develop. The patient received full-enteral nutrition and achieved weight gain. He was discharged without vomiting on the $23^{\text {rd }}$ day after birth.

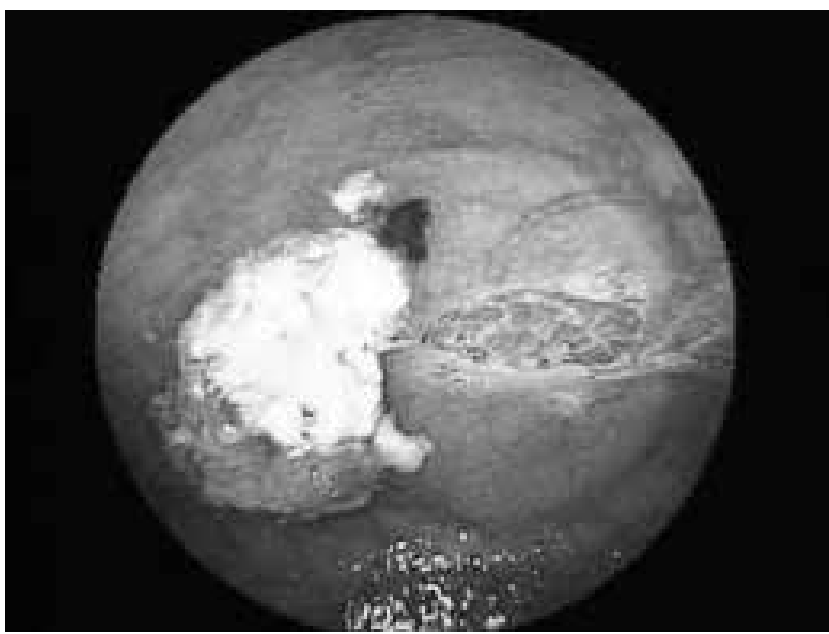

Figure 1. Endoscopic appearance of the duodenal heterotopic pancreas 


\section{Discussion}

$\mathrm{PH}$, defined by a pancreatic tissue outside the usual pancreatic location, most often becomes symptomatic in the elderly, but may manifest at any age including neonates (3). Because many patients are asymptomatic, the actual incidence of $\mathrm{PH}$ is unknown; it is rare in children and more prevalent among girls in childhood (4-7). Ogata et al. (6) reported a $\mathrm{PH}$ incidence of $0.44 \%$ in children, and 6 out of 12 patients were diagnosed in the neonatal period. We herein presented a case of $\mathrm{PH}$ in a male newborn, because this condition is rarely considered and diagnosed in the neonatal period, being commonly asymptomatic at this age. Our case with $\mathrm{PH}$ suffered bilious vomiting within the first week after birth.

The clinical symptoms of $\mathrm{PH}$ are non-specific, depending on the location and size of the lesion, besides the involvement of overlying mucosa. Autopsy series have demonstrated that heterotopic pancreatic tissue may enlarge with age and become symptomatic, and the initial symptom may be vomiting. Epigastric pain, tarry stool, abdominal fullness, dyspepsia, gastric ulcers, changes in bowel habit, obstructive jaundice, vomiting, weight loss, and gastrointestinal bleeding are reported in adults $(3,4,6)$. Occasionally, it may cause invagination or intussusception $(8,9)$. The heterotopic pancreatic tissue can undergo complications such as inflammation (acutechronic pancreatitis, and abscess), obstruction (gastric outletjejunal obstruction), pseudocyst formation and malignant transformation (7). Rare manifestations and complications include hyperinsulinism and Zollinger-Ellison syndrome. Olguner et al. (10) reported a 12-year-old girl with a longlasting history of sporadic bilious vomiting due to a $2 \times 2 \mathrm{~cm}$ jejunal $\mathrm{PH}$; they suggested that $\mathrm{PH}$ causes dysmotility and/ or local spasm. We assume that our case with $\mathrm{PH}$ became symptomatic as bilious vomiting due to mass effect.

$\mathrm{PH}$ is most commonly located submucosally $(75 \%)$ in the upper gastrointestinal tract; followed by stomach (25-38\%), duodenum (17-36\%), jejunum (15-21\%), bowel diverticula (7.3\%), and Meckel's diverticulum (5.3\%) in adults. PH located

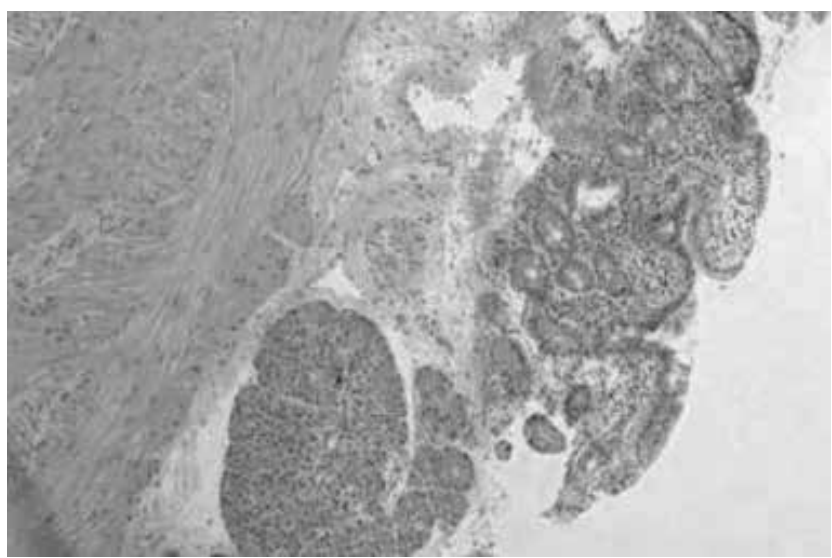

Figure 2. Histopathological appearance of the duodenal heterotopic pancreas in the esophagus, gallbladder, ampulla of vater, common bile duct, choledochus, liver, spleen, lungs, omentum, colon, mediastinum, lymph nodes, urinary bladder, and fallopian tubes is rarely described. It may also be observed as an umbilical polypoid tissue $(3,4)$. The lesion is commonly located in the stomach, duodenum and jejunum in neonates $(3,6,7,11)$. In the reported case, $\mathrm{PH}$ was observed in the second part of the duodenum. There is no specific method for the diagnosis of $\mathrm{PH}$, and preoperative diagnosis is difficult (3). Upper gastrointestinal contrast study and endoscopy are important for the definition of the lesion. Typical findings are filling defect and the appearance of central umbilication. Computed tomography reveals non-specific findings, and gastrointestinal endoscopy should determine small lesions not demonstrable by radiological examination. If there is no central umbilication, distinguishing $\mathrm{PH}$ from other lesions of similar appearance (i.e., leiomyoma, lymphoma, adenomatous polyp, stromal tumor, and polypoid form of gastric carcinoma) is difficult. Endoscopic biopsy may be difficult and a definite diagnosis is often made only by surgical excision. Capsule endoscopy and enteroscopy are new methods for detecting the lesion (12). Histological examination of the biopsy obtained by endoscopic ultrasound-guided fine needle aspiration has a sensitivity of $80-100 \%$ and is considered as the gold standard for diagnosis (12). In the reported case, upper gastrointestinal contrast study demonstrated delayed passage, while gastrointestinal endoscopy demonstrated a submucosal mass in the second part of the duodenum causing partial obstruction. The diagnosis was made by histopathological examination.

The pathogenesis of $\mathrm{PH}$ is not well-understood and several theories have been hypothesized; theories of misplacement and metaplasia are the most likely ones (13). Heinrich defined three types of $\mathrm{PH}$ in 1973 and four types were modified by Gaspar Fuentes et al. (14). Type I heterotopia consists of typical pancreatic tissue with acini, ducts, and islet cells similar to those observed in the normal pancreas. Type II heterotopia consists of pancreatic ducts only, referred to as canalicular type. Type III heterotopia is characterized by acinar tissue only (exocrine pancreas). Our case was considered as type II according to the classification by Gaspar Fuentes et al. (14).

In summary, $\mathrm{PH}$ is a rare and asymptomatic disorder in the neonatal period, turning its diagnosis into a challenge. It is usually located in the stomach, duodenum and jejunum in the neonatal period. Although relatively rare, $\mathrm{PH}$ should be considered in the differential diagnosis of neonates with vomiting and feeding intolerance due to mass effect. The mass must be excised, if the symptoms develop.

\section{Ethics}

Informed Consent: It was taken.

Peer-review: Externally and Internally peer-reviewed.

\section{Authorship Contributions}

Surgical and Medical Practices: Ceyda Tuna Kırsaçlığlu, Concept: Betül Siyah Bilgin, Sevim Ünal, Design: Betül Siyah Bilgin, Deniz Gönülal, Data Collection or Processing: Betül 
Siyah Bilgin, Analysis or Interpretation: Sevim Ünal, Literature Search: Deniz Gönülal, Writing: Betül Siyah Bilgin.

Conflict of Interest: No conflict of interest was declared by the authors.

Financial Disclosure: The authors declared that this study received no financial support.

\section{References}

1. De Castro Barbosa JJ, Dockerty MB, Waugh JM. Pancreatic heterotopia; review of the literature and report of 41 authenticated surgical cases, of which 25 were clinically significant. Surg Gynecol Obstet 1946;82:527-42.

2. Inoue $Y$, Hayashi $M$, Arisaka $Y$, Higuchi $K$, Egashira $Y$, Tanigawa N. Adenocarcinoma arising in a heterotopic pancreas (Heinrich type III): a case report. J Med Case Rep 2010;4:39

3. Gupta MK, Karlitz JJ, Raines DL, Florman SS, Lopez FA. Clinical case of the month. Heterotopic pancreas. J La State Med Soc 2010;162:310-3.

4. Shetty A, Paramesh AS, Dwivedi AJ. Symptomatic ectopic pancreas. Clin Rev 2002;58:203-7.

5. Ormarsson OT, Gudmundsdottir I, Marvik R. Diagnosis and treatment of gastric heterotopic pancreas. World J Surg 2006;30:1682-9.

6. Ogata H, Oshio T, Ishibashi H, Takano S, Yagi M. Heterotopic pancreas in children: review of the literature and report of 12 cases. Pediatr Surg Int 2008;24:271-5.
7. Ueno $\mathrm{S}$, Ishida $\mathrm{H}$, Hayashi A, Kamagata S, Morikawa M. Heterotopic pancreas as a rare cause of gastrointestinal hemorrhage in the newborn: report of a case. Surg Today 1993;23:269-72

8. Singh S, Batra A, Sangwaiya A, Marwah N, Rattan K, Sen R. Heterotopic pancreas presenting as ileoileal intussusception. J Surg Case Rep 2012;2012:13.

9. Tekin A, Aksoy F, Vatansev C, Kucukkartallar T, Belviranli M, Toy $\mathrm{H}$. A rare cause of ileus: invagination due to ectopic pancreas. Acta Chir Belg 2008;108:343-5.

10. Olguner M, Ozdemir T, Ates O, Akgur FM, Aktug T, Ozer E. A case of proximal jejunal ectopic pancreas causing sporadic vomiting. Turk J Pediatr 2003;45:161-4.

11. Saka R, Gomi A, Sugiyama A, et al. Ectopic pancreas as a cause of jejunal obstruction in a neonate. J Pediatr Surg 2009;44:856-8.

12. Rocha HL, Bueno FK, Faraco J, et al. Heterotopic pancreas complicated by pseudocyst in the gastric wall diagnosed by endoscopic ultrasound-guided fine needle aspiration. Endosc Ultrasound 2013;2:159-61.

13. Trifan A, Tarcoveanu E, Danciu M, Hutanasu C, Cojocariu C, Stanciu C. Gastric heterotopic pancreas: an unusual case and review of the literature. J Gastrointestin Liver Dis 2012;21:209-12.

14. Gaspar Fuentes A, Campos Tarrech JM, Fernandez Burgui $\mathrm{JL}$, et al. [Pancreatic ectopias]. Rev Esp Enferm Apar Dig 1973;39:255-68 